J. Product. \& Dev., 12(2): 509 - 523(2007)

\title{
IN VITRO DEVELOPMENT OF VITRIFIED RABBIT EMBRYOS: EFFECT OF DOE HORMONAL TREATMENTS AND EMBRYO DEVELOPMENTAL STAGES
}

\author{
Samia Z. Meshreky, Salama O. A. and Eitedal H. EL-Sayed
}

Animal Production Research Institutes, Agriculture Research center, Dokki, Geza, Egypt.

\begin{abstract}
The effects of donors hormonal treatment and embryo developmental stages on the survival of vitrified rabbit embryos were examined. Thirty six virgin New Zealand White rabbit does aging 6-7 months were divided in two groups. Does in the $1^{\text {st }}$ group $(n=24)$ were treated with intramuscular injection of $20 \mu \mathrm{g} G \mathrm{GHH} / \mathrm{doe}$ for induction of ovulation and artificially inseminated. Does in the $2^{\text {nd }}$ group $(n=12)$ were treated with subcutaneous injection of $80 I U$ PMSG/doe and $68 \mathrm{~h}$ later with intravenous injection of $50 \mathrm{IU} h \mathrm{CG} / \mathrm{doe}$ for the induction of superovulation and artificially inseminated following $h C G$ administration. Eight and four does from the $1^{\text {st }}$ and $2^{\text {nd }}$ groups respectively were slaughtered in each of 24-26, 48-50 and 72-74 $h$ after insemination for embryo collection. Embryos at various developmental stages were vitrified. Upon de-vitrification, embryos were evaluated for viability as indicated by the morphological appearance and subsequent development in culture medium for $48 \mathrm{~h}$.

The percentage of normal embryos vitrified and embryos post-thawing with morphologically normal appearance recovered from GnRH treated does were higher than that obtained from superovulated donors (93.05 vs. $77.43 \%$ and 75.86 vs. $67.43 \%$, respectively). Only 63 (36\%) of 175 superovulated embryo vitrified was cleaved in vitro post-vitrification compared to 89 (51.15\%) of 174 control embryos. No significant differences were observed among embryo developmental stages in the percentage of vitrified normal embryos. The percentages of embryos recovered post-vitrification with morphologically normal appearance were significantly $(P<0.05)$ higher in later developmental stages compared to earlier stages. The best percentage of embryos developed in vitro have been obtained after de-vitrification at the early blastocyst stage, followed by that at compacted morulae and morulae stages, whereas the lower percentage were recorded with embryos vitrified at 2and 4- cell stages. Markedly high in vitro development rates (84.85-92.31\%) were obtained in morulae, compacted morulae and early blastocyst stages in control embryos compared to 63.33-81.48\% in embryos produced through superovulation. These results show that treating donor with GnRH achieve the best embryos for cryopreservation and also rabbit embryos at morulae, compacted morulae and early blastocyst stages are appear to be proper candidate stages for cryopreservation.
\end{abstract}

Key words: Rabbits, superovulation, embryos developmental stages, vitrification. 


\section{INTRODUCTION}

Cryopreservation enables banking of embryos for future use in medicine and in animal breeding. It also enables protection of germ plasm of endangered species and unique strains or lanes of laboratory animals (Papis et al., 2005). Superovulation is considered to be an efficient economic method for producing additional embryos or oocytes from females of high genetic merit. For most domestic animals, the responses to superovulation treatments are not controlled as a consequence of the lack of knowledge on exogenous gonadotrophins effects on the ovarian function. Furthermore, the response to superovulation treatments is highly variable. This variability has several origins like genetic, age, breeding, parity, physiological status of the animals (Takagi et al., 2001) and the hormonal preparations used are very important too (Salvetti et al., 2007). Few comparative studies have been carried out on the hormonal treatment used for ovulation induction in relation to embryo recovery and its in vitro and in vivo survival rates in rabbits (García-Ximénez and Vicente, 1992, Viudes-de-Castro et al., 1995, García et al., 2000 and Vicente et al., 2003).

Survival of cryopreserved rabbit embryos depends on the embryonic stage of development and on the cryoprotective additives; although $32 \%$ of 774 rabbit oocytes frozen in $\mathrm{PG}+$ sucrose appeared morphologically normal after freezing and thawing, only $14 \%$ cleaved to the 2- to 8-cell stages after in vitro fertilization (Al-Hasani et al., 1989). The cytoskeleton and meiotic spindle, oocytes are even more sensitive to cryopreservation (Vincent et al., 1989). In addition, Hochi et al. (2001) demonstrated that pronuclear stage rabbit zygotes could be successfully cryopreserved in a solution of EG plus sucrose. Only $18 \%$ of rabbit zygotes vitrified in a mixture of EG+Ficoll+sucrose (EFS) solution developed into blastocysts. With 2-cell stage rabbit embryos, in vitro survival has ranged from 58\% developing to blastocysts for 101 embryos vitrified in EFS (Smorag and Gajda, 1998), to 89\% developing into morulae for 54 embryos frozen in PG (Renard et al., 1982). Only $40 \%$ of 176 morulae vitrified in EG alone or in EG+DMSO, developed into blastocysts (Vicente and Garcia-Ximenez, 1994); 72\% of 281 rabbit morulae frozen by equilibrium cooling in DMSO, developed into blastocysts in vitro (Kojima et al., 1987); however, 89\% developed into blastocysts of 235 morulae vitrified in EFS (Kasai et al., 1992). Thus, it is clear that rabbit zygotes are rather difficult to be cryopreserved compared to later stage embryos.

The objectives of this study were to examine the effects of hormonal treatment of does on the morphological appearance and in vitro development of rabbit embryos vitrified in dimethyl-sulphoxide (DMSO) and ethylene glycol (EG) at different preimplantation stages. 


\title{
MATERIALS AND METHODS
}

This experimental work was carried out at the laboratory of Reproduction and Biotechnology, Animal Production Research Institute, Agricultural Research Center, Ministry of Agriculture, Egypt.

\begin{abstract}
Animals
Thirty six nulliparous New Zealand White female rabbits aging 6-7 months old were used as donors. Animals were housed in individual metal cages for 3 weeks perior to hormonal treatments to eliminate the chances of pseudopregnancy. Five rabbit bucks of proven fertility of the same breed were also utilized. The animals were kept under controlled 16h light: $8 \mathrm{~h}$ dark photoperiod and fed ad-libitum with a commercial pelleted diet contained $18.4 \%$ crude protein, $14.0 \%$ crude fibers and $2.4 \%$ fat. Fresh potable water was made available all times through stainless nipples.
\end{abstract}

\section{Embryo recovery}

Experimental does were divided into two groups. Does in the first group (24 does) were treated with an intramuscular injection of $20 \mu \mathrm{g}$ GnRH (Fertagyl, Intervet, International B. V. Boxineer-Holland) followed by artificial insemination (AI) with fresh semen. Does in the second group (12 does) were administered subcutaneously with $80 \mathrm{IU}$ PMSG/doe (Folligon, Intervet, International B. V. Boxineer-Holland) followed $68 \mathrm{~h}$ later with intravenous injection (iv) of $50 \mathrm{IU}$ hCG/doe (Pregnyl, Organon, Nile Co., Egypt). Does were inseminated at the time of hCG injection. Eight does from $1^{\text {st }}$ group and four does from $2^{\text {nd }}$ group (superovulation) were slaughtered at 24-26, 48-50 and 72-74 h after insemination. The reproductive tracts (oviducts and uterine horns) were removed and embryos stages were recovered by flushing twice with $5 \mathrm{~mL}$ of Dulbecco's Phosphate Buffered Saline (®DPBS, (PBS: Gibco, Cat. No 21300-017, UK) supplemented with $\mathrm{CaCl}_{2}(0.132 \mathrm{~g} / \mathrm{L}), 0.2 \%$ of bovine serum albumin (®BSA, Sigma Chemical Co., St. Louis, Mo, USA) and antibiotics (10,000 IU Penicillin G potassium $+10 \mathrm{mg}$ streptomycin sulfate $/ \mathrm{ml}$, Sigma) at room temperature $\left(20-25^{\circ} \mathrm{C}\right)$. After recovery, embryos and oocytes were washed twice in fresh DPBS supplemented with $10 \%$ FCS and antibiotics, counted and morphologically evaluated under stereoscopic microscope. Embryos with no abnormalities in mucin coat, zona pellucida and with homogenous blastomeres were scored as freezable embryos (grade 1 or 2) according to International Embryo Transfer Society classification. The other embryos were considered as grade 3 embryos (nonfreezable). Morphologically normal embryos (grade 1 or 2) from each donor doe were washed twice in fresh DPBS and kept within 15-30 min. at ambient temperature, away of light, until vitrification 


\section{Vitrification procedure}

Grade 1 and 2 embryos collected from treated does at different developmental stages were vitrified and devitrified using the method described by Vicente et al. (1999). The cryoprotective solution was a $1: 1: 2$ solution $(\mathrm{v} / \mathrm{v} / \mathrm{v})$ of dimethyl-sulfoxide $(3.5 \mathrm{M}$ DMSO, Sigma), ethylene glycol (4.4 M EG, Sigma), in DPBSCa (DPBS supplemented with $0.132 \mathrm{~g} \mathrm{CaCl}_{2} / \mathrm{L}$ ) supplemented with $0.2(\mathrm{w} / \mathrm{v})$ bovine serum albumin (BSA; Sigma) per liter of cryoprotective solution.

Vitrification was carried out in two steps. First, normal embryos were pipetted into $0.2 \mathrm{ml}$ of PBS medium and placed in a culture dish and then $0.2 \mathrm{ml}$ of the cryoprotective solution was added and agitated. Embryos were kept in this medium for 2 minutes. In the second step, $0.6 \mathrm{ml}$ of the cryoprotective solution was added and quickly agitated. Then, embryos suspended in the final vitrification solution were loaded into $0.25 \mathrm{ml}$ plastic straws (IMV, L'Aigle, France), sealed with polyvinyl-alcohol sealing powder and plunged directly into liquid nitrogen. The exposure time of embryos to the final vitrification solution did not exceed 1 minute. The two vitrification steps were carried out at $20^{\circ} \mathrm{C}$. The straws contained three sections separated by air bubbles. The first consisted of PBS in the cotton plug, the second section contained the embryos suspended in vitrification medium $(0.1 \mathrm{ml})$ and the third section consisted of PBS. The straws were sealed and identified. Each straw held between 5 to 8 normal embryos.

Devitrification was performed by immersing the second and third sections of the straws in a water bath at $20{ }^{\circ} \mathrm{C}$ for $10-15 \mathrm{sec}$. The cryoprotective solution was removed from the embryos in a two step dilution procedure at room temperature $\left(20-25{ }^{\circ} \mathrm{C}\right)$. Embryos suspended in the final vitrification solution were released into a culture dish containing $1 \mathrm{ml}$ of $0.33 \mathrm{M}$ sucrose in PBS medium. After 5 minutes, embryos were washed twice in fresh PBS medium and morphologically scored before culture. Only embryos with homogenous cell mass and intact zonae pellucida were in vitro cultured.

\section{Post-vitrification in vitro development}

Embryos were cultured for $48 \mathrm{~h}$ in $50 \mu \mathrm{l}$ microdrops of Ham's F10 medium $+20 \%$ FBS (Sigma) under mineral oil (Sigma) at $38.5{ }^{\circ} \mathrm{C}$ in $5 \% \mathrm{CO}_{2}$ and saturated humidity. The in vitro cleaved and development ability of devitrified embryo and quality were assessed and recorded for analysis.

\section{Statistical Analysis}

A Chi-square test was used to compare the effect of hormonally treated donors and embryo stage on the pre and post-vitrification quality and in vitro development of embryos. 


\section{RESULTS AND DISCUSSION}

\section{Effect of hormonal treatment}

Results in Table (1) showed that the percentage of verifiable embryos recovered from the GnRH treated does (control group) was higher than that obtained from PMSG+hCG treated donors (superovulated group, 93.05 vs. $77.43 \%$ ), difference was not statistically significant. This may due to the effect of the superovulatory treatment as several authors have observed negative effect of superovulatory treatment on embryo production (García-Ximénez and Vicente, 1990), embryo recovery rates (Schmidt et al., 1992 and Meshreky and Salama, 2005) and on the survival rate of rabbit embryos (Maertens et al., 1995 and Rebollar et al., 2000). Moreover, superovulation treatment cause the ovulation of a high number of abnormal haemorrhagic and cystic follicles (García-Ximénez and Vicente, 1990) and defaults of ovulation (Salvetti et al., 2007). Several authors observed that the administration of exogenous gonadotrophins decreases the frequency and the amplitude of the pulsatile endogenous LH secretion linked with an increase of estradiol and progesterone plasmatic concentrations (Ben Jeraba et al. 1994 and Gosselin et al., 2000). As the estrogen concentration increases, the LH concentration decreases and would become inadequate to activate the positive feedback of the estradiol on the LH secretion by the hypothalamus during the preovulatory period. Further, the absence of estrogens' positive feedback was underlined by Ramirez and Beyer (1998) and Bakker and Baum (2000) to explain the absence of spontaneous ovulation in induced ovulators. Thus, the larger amount of estradiol could inhibit the preovulatory pulse of LH and the ovulation mechanism. Mehaisen et al. (2005) observed that the number of ovulation sites tended to be higher with a dose of $200 \mathrm{IU}$ eCG/doe in superovulated does, it did not improve the number of normal embryos recovered and had a negative effect on the in vitro development of embryos after thawing when compared to $50 \mathrm{IU}$ eCG/doe. In addition, Salvetti et al. (2007) reported that superovulation treatments were associated with a significant increase of the number of corpora lutea present on the ovaries, hemorrhagic follicles, the number of embryos recovered, good quality embryos, bad quality embryos and of "non-freezable" eggs per female donor in comparison with the control group. Confirming Kennelly and Foote (1965) observations, the gonadotrophins stimulations of the ovaries which led to an increase of the number of hemorrhagic follicles may be attributable to the supra-physiological amount of gonadotrophins administrated, involving the precocious apoptosis of the granula's cells and leading to the follicles atresia.

Results in Table (1) and Plate (1) revealed that the percentage of embryos recovered from superovulated does with post-thawing morphologically normal appearance was lower than that recovered from GnRH treated does (67.43 vs. 75.86\%). Structurally intact embryos and high morphological quality grade may be essential components for successful rabbit embryo cryopreservation. Rebollar et al. (2000) reported that 
cryopreservation of rabbit embryos led to a higher rate of morphological damage when recovered from superovulated does compared with untreated one. Mehaisen et al. (2006) also reported that the primary treatments with eCG or FSH increased the number of normal embryos recovered per a donor doe, but these embryos are more sensitive to vitrification protocols. However, superovulation may cause the cytogenesis defects and chromosomal alterations of recovered embryos (Carney and Foote, 1990; Chrenek et al., 1998 and Kauffman et al., 1998). In addition, Yaakub et al. (1998) observed in heifers that a higher superovulatory response could produce an inferior embryo quality.

Table 1. Effect of hormonal treatment on pre and post vitrification embryo quality.

\begin{tabular}{lcccc}
\hline $\begin{array}{l}\text { Donor } \\
\text { hormonal } \\
\text { treatments }\end{array}$ & $\begin{array}{c}\text { No. } \\
\text { embryos } \\
\text { recovered }\end{array}$ & $\begin{array}{c}\text { Embryos } \\
\text { vitrified } \\
\boldsymbol{n}(\boldsymbol{\%})^{\mathbf{1}}\end{array}$ & $\begin{array}{c}\text { Morphologically } \\
\text { normal embryos } \\
\text { post-thawing } \\
\boldsymbol{n}(\boldsymbol{\%})^{\mathbf{2}}\end{array}$ & $\begin{array}{c}\text { Embryos cleaved and } \\
\text { developed } \\
\text { in vitro } \\
\boldsymbol{n}(\%)^{\mathbf{3}}\end{array}$ \\
\hline GnRH & 187 & $174(93.05)$ & $132(75.86)$ & $89(67.42)$ \\
PMSG+hCG & 226 & $175(77.43)$ & $118(67.43)$ & $63(53.39)$ \\
\hline
\end{tabular}

${ }^{1}$ Percentage based on the number of embryos recovered.

${ }^{2}$ Percentage based on the number of embryos vitrified.

${ }^{3}$ Percentage based on the number of morphologically normal embryos post-thawing.

Embryos produced by superovulation were inferior as to in vitro post vitrification development compared to those from the control group (Table 1 \& Plate 1). Only 63 $(36 \%)$ of 175 superovulation produced vitrified embryos did cleave in vitro compared to $89(51.15 \%)$ of 174 control embryos. Mehaisen et al. (2005) also found that 200 IU eCG in superovulated does did not improve the number of normal embryos recovered and had a negative effect on the in vitro development of embryos after thawing when compared to 50 IU eCG. In addition, Mehaisen et al. (2006) obtained successful results of embryo viability only in the control group (without superovulation treatment), 67.9\% in vitro development to hatched blastocyst stage after vitrification. Moreover, Parvex (1982) found that superovulation treatment affected the development of embryos in vitro and in vivo and resulted in abnormality and death of embryos after transfer. However, Salvetti et al. (2007) reported that no significant differences were observed between superovulated does and control group for in vitro development of embryos thawed after cryopreservation reached expanded blastocyst stage. All of these reports with our results indicate that embryos recovered from superovulated donors, although may have normal morphological 
A

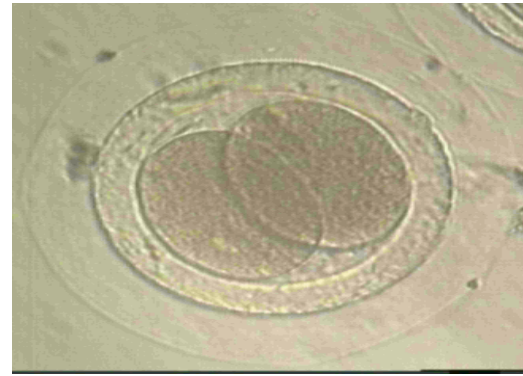

$\mathrm{C}$

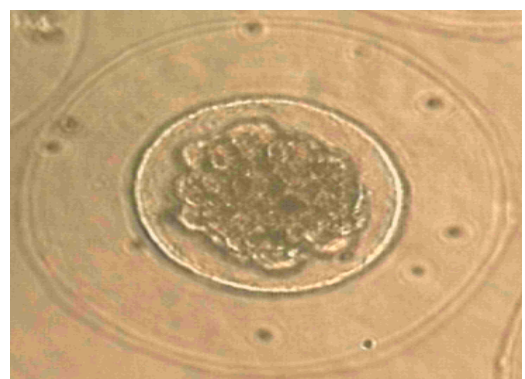

E

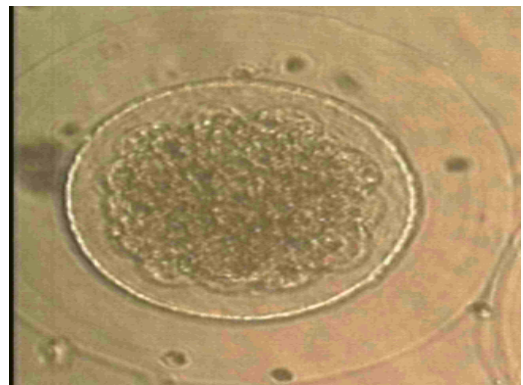

G

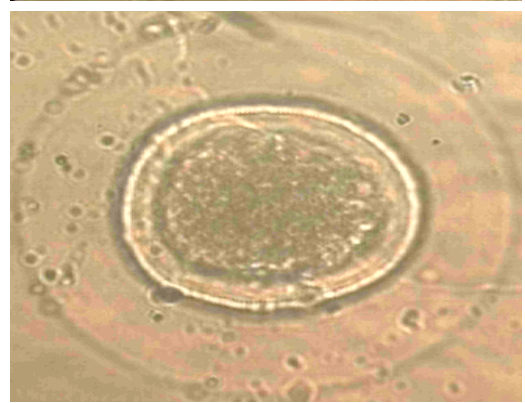

$\mathrm{B}$

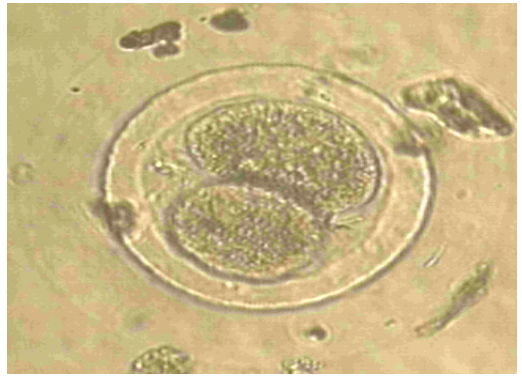

$\mathrm{D}$

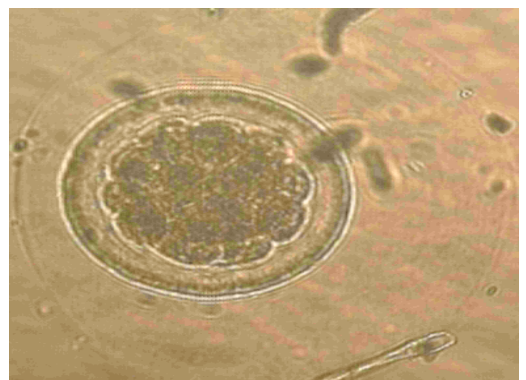

$\mathrm{F}$

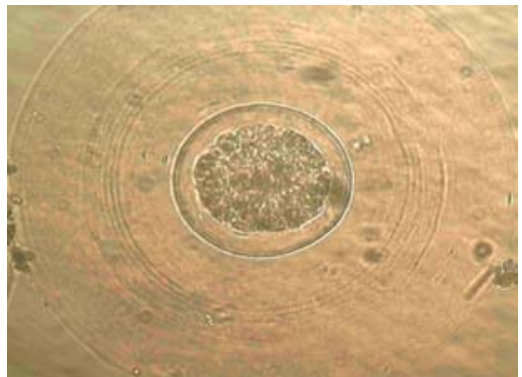

$\mathrm{H}$

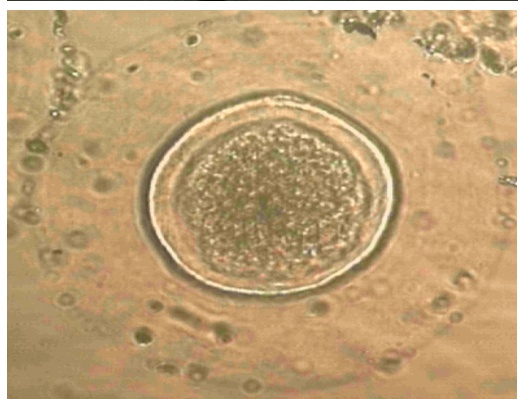

Plate 1. Pre and post vitrification rabbit embryos: (A \& B) 2-cell stage (superovulated does). (C \& D) 16-cell (superovulated does). (E \& F) Compacted morula (GnRH treated does). ( $\mathrm{G} \& \mathrm{H}$ ) Early blastocyst developed from vitrified superovulated rabbit morula, 
appearance, exhibit lower developmental potential than embryos recovered from nonsuperovulated donors (Kauffman et al., 1998). The higher sensitivity of embryos recovered from superovulated does to low temperatures leads to a decrease in their subsequent potential capacity for development after vitrification (Leoni et al., 2001). Vajta (2000) explained the lower viability rate after vitrification based on the number of trophoblastic cells and inner cell mass per embryo. The surviving blastomeres after vitrification procedures may be insufficient in number to permit the re-expansion of the blastocoelic cavity and continue the physiological development.

\section{Effect of embryo developmental stages}

No significant differences were observed among embryo developmental stages in the percentage of embryos vitrified (Table 2). However, Lopez-Bejar and Lopez-Gatius (2002) reported that blastocyst stages yielded best results compared to earlier stages of development for the cryopreservation of rabbit embryos.

The percentages of embryos with post-vitrification morphologically normal appearance were significantly $(\mathrm{P}<0.05)$ higher in later developmental stages compared to earlier stages (Table 2). These may be related to exposure of embryos to high levels of cryoprotective solutions which induce deleterious effects on the embryo development after devitrification (Gajda and Smorag, 1993; Kasai et al., 1996; Leoni et al., 2001 \& 2003), especially at the early fetal development (Mocé et al., 2004).

Table 2. Effect of embryo developmental stage on pre and post vitrification embryo quality and development.

\begin{tabular}{lcccc}
\hline $\begin{array}{c}\text { Developmental } \\
\text { stages }\end{array}$ & $\begin{array}{c}\text { No. } \\
\text { embryos } \\
\text { recovered }\end{array}$ & $\begin{array}{c}\text { Embryos } \\
\text { vitrified } \\
\boldsymbol{n}(\%)^{\mathbf{1}}\end{array}$ & $\begin{array}{c}\text { Morphologically } \\
\text { normal embryos } \\
\text { post-thawing } \\
\boldsymbol{n}(\boldsymbol{\%})^{\mathbf{2}}\end{array}$ & $\begin{array}{c}\text { Embryos cleaved and } \\
\text { developed } \\
\text { in vitro } \\
\boldsymbol{n}(\%)^{\mathbf{3}}\end{array}$ \\
\hline 2-cell & 65 & $56(86.15)$ & $29(51.79)^{\mathrm{c}}$ & $7(24.14)^{\mathrm{c}}$ \\
4-cell & 68 & $57(83.82)$ & $37(64.91)^{\mathrm{bc}}$ & $11(29.73)^{\mathrm{c}}$ \\
16-cell & 68 & $61(89.71)$ & $47(77.05)^{\mathrm{ab}}$ & $24(51.06)^{\mathrm{b}}$ \\
Morulae & 97 & $77(79.38)$ & $59(76.62)^{\mathrm{ab}}$ & $44(74.58)^{\mathrm{a}}$ \\
Compact Morular & 88 & $74(84.09)$ & $60(81.08)^{\mathrm{a}}$ & $50(83.33)^{\mathrm{a}}$ \\
Early blastocyst & 27 & $24(88.89)$ & $18(75.00)^{\mathrm{ab}}$ & $16(88.89)^{\mathrm{a}}$ \\
\hline
\end{tabular}

${ }^{1}$ Percentage based on the number of number of embryos recovered.

${ }^{2}$ Percentage based on the number of embryos vitrified.

${ }^{3}$ Percentage based on the number of morphologically normal embryos post-thawing.

a,b,c Values with different superscripts in the same column differ significantly $(P<0.05)$. 
The highest percentage of embryos cleaved in vitro have been obtained after devitrification at early blastocyst stage, flowed by that at compacted morulae and morulae stages, whereas the lower percentage were recorded with embryos vitrified at 2- and 4cell stages (Table 2). The results agree with those repored by Lopez-Bejar et al. (1994) who found that all embryonic stages (2-cell, 8 to 16-cell, compacted morula and early blastocyst stages of rabbit embryos studied developed in vitro after cooling procedure; however, the best results were obtained at compacted morula and blastocyst stages. Whereas, Lopez-Bejar and Lopez-Gatius (2002) observed lower rates of in vitro development when the embryos were cryopreserved at the morula stage and higher rates achieved using rabbit embryos at blastocyst stage. However, Kobayashi et al. (1990) found the higher embryo survival rates after de-vitrification in the rabbit at the morula stage, indicating that morulae seem to tolerate osmotic changes and the toxicity of cryoprotectants and this embryo stage allows the conventional freezing procedures to be substituted efficiently by a simple method of vitrification. Ogawa and Tomoda (1976) also recorded that $69 \%$ morulae stage developed in vitro after frozen-thawing compared with $51 \%$ only of 16 -cell rabbit embryo stage. The previous reports and our results confirm that the development stage of the cryopreserved embryo significantly affects the viability rates of rabbit morulae and blastocysts. This effect is generally observed when rabbit embryos are cryopreverved at earlier stages (2- to 4-cell embryos) (Smorag et al., 1989). The ratio of cell surface to volume is one of the major factors determining survival following cryopreservation (Mazur et al., 1984). Thus, the factors associated blastomere size and membrane permeability to water and cryoprotectants have been related to the reduced viability of embryos cryopreserved at initial stages of development (Schneider and Mazur, 1984 and Gajda and Smorag, 1993). In addition, Pollard and Leibo (1994) and (Nagashima et al., 1995) mentioned that both cell size and lipid content of zygotes are factors thought to influence their sensitivity to cryoprotective additives (CPAs) and to cryopreservation.

\section{Effect of donor hormonal treatment and embryo developmental stage}

Superovulation produced embryos yielded lower values as to the percentage of normal verifiable embryos compared to those in the GnRH treated does especially at early developmental stages (Table 3 and Plate 1). Only $78.38 \%$ of 37 superovulation produced embryos recovered were vitrified compared to $96.43 \%$ of 28 control embryos at 2-cell stage, whereas 77.78 and $80.00 \%$ superovulation produced embryos at compacted morulae and early blastocyst stages were vitrified compared to 90.70 and $94.12 \%$ in $\mathrm{GnRH}$ produced embryo at the same developmental stages. In addition, it is indicated that the percentages of the devitrified embryos with morphologically normal appearance ranged from 44.83 to $85.0 \%$ including all developmental stages with different hormonal treatment with an average of $71.63 \%$. However, the developmental ability of 2 - and 4-cell embryos was low than other developmental stages (Table 3). In vitro survival rates of 
later stage embryos were significantly higher than earlier stages, especially with superovulation produced embryos. Very high in vitro cleavage and development rates (84.85-92.31\%) were obtained with morulae, compacted morulae and early blastocyst in control group embryos compared to $63.33-81.48 \%$ in superovulation produced embryos.

In this experiment, the overall numbers of collected embryos were 413 out of which 349 embryos were considered for vitrification (84.5\%), although $60.53 \%$ (250/413) appeared morphologically normal after thawing, only $36.80 \%(152 / 413)$ continued to develop when cultured in vitro. These results showed that treating rabbit donors with GnRH yielded better embryos for cryopreservation and that embryos at the 2-cell to early blastocyst stages could soundly be vitrified, and that the morulae, compacted morulae and early blastocyst stages are potentially suitable candidates for vitrification.

Table 3. Rates of morphologically normal rabbit embryos cryopreserved at different developmental stages as affected by donor hormonal treatments.

\begin{tabular}{|c|c|c|c|c|c|}
\hline $\begin{array}{c}\text { Embryos } \\
\text { developmental } \\
\text { stages }\end{array}$ & $\begin{array}{c}\text { Donor } \\
\text { treatments }\end{array}$ & $\begin{array}{c}\text { No. } \\
\text { embryos } \\
\text { recovered }\end{array}$ & $\begin{array}{c}\text { Embryos } \\
\text { vitrified } \\
n(\%)^{1}\end{array}$ & $\begin{array}{c}\text { Morphologically } \\
\text { normal embryos } \\
\text { post-thawing } \\
n(\%)^{2}\end{array}$ & $\begin{array}{c}\text { Embryos } \\
\text { developed } \\
\text { in vitro } \\
n(\%)^{3}\end{array}$ \\
\hline 2-cell & $\begin{array}{l}\text { GnRH } \\
\text { PMSG+hCG }\end{array}$ & $\begin{array}{l}28 \\
37\end{array}$ & $\begin{array}{l}27(96.43)^{\mathrm{a}} \\
29(78.38)^{\mathrm{b}}\end{array}$ & $\begin{array}{l}16(59.26)^{\mathrm{a}} \\
13(44.83)^{\mathrm{b}}\end{array}$ & $\begin{array}{l}5(31.25)^{\mathrm{a}} \\
2(15.38)^{\mathrm{b}}\end{array}$ \\
\hline 4-cell & $\begin{array}{l}\text { GnRH } \\
\text { PMSG+hCG }\end{array}$ & $\begin{array}{l}39 \\
29\end{array}$ & $\begin{array}{l}36(92.31)^{\mathrm{a}} \\
21(72.41)^{\mathrm{b}}\end{array}$ & $\begin{array}{l}24(66.67)^{\mathrm{a}} \\
13(61.91)^{\mathrm{a}}\end{array}$ & $\begin{array}{l}8(33.33)^{\mathrm{a}} \\
3(23.08)^{\mathrm{a}}\end{array}$ \\
\hline 16-cell & $\begin{array}{l}\text { GnRH } \\
\text { PMSG+hCG }\end{array}$ & $\begin{array}{l}20 \\
48\end{array}$ & $\begin{array}{l}20(100.0)^{\mathrm{a}} \\
41(85.42)^{\mathrm{a}}\end{array}$ & $\begin{array}{l}17(85.00)^{\mathrm{a}} \\
30(73.17)^{\mathrm{a}}\end{array}$ & $\begin{array}{l}11(64.71)^{\mathrm{a}} \\
13(43.33)^{\mathrm{b}}\end{array}$ \\
\hline Morulae & $\begin{array}{l}\text { GnRH } \\
\text { PMSG+hCG }\end{array}$ & $\begin{array}{l}40 \\
57\end{array}$ & $\begin{array}{l}36(90.00)^{\mathrm{a}} \\
41(71.93)^{\mathrm{b}}\end{array}$ & $\begin{array}{l}29(80.56)^{\mathrm{a}} \\
30(73.17)^{\mathrm{a}}\end{array}$ & $\begin{array}{l}25(86.21)^{\mathrm{a}} \\
19(63.33)^{\mathrm{b}}\end{array}$ \\
\hline C. Morulae & $\begin{array}{l}\text { GnRH } \\
\text { PMSG+hCG }\end{array}$ & $\begin{array}{l}43 \\
45\end{array}$ & $\begin{array}{l}39(90.70)^{\mathrm{a}} \\
35(77.78)^{\mathrm{a}}\end{array}$ & $\begin{array}{l}33(84.62)^{\mathrm{a}} \\
27(77.14)^{\mathrm{a}}\end{array}$ & $\begin{array}{l}28(84.85)^{\mathrm{a}} \\
22(81.48)^{\mathrm{a}}\end{array}$ \\
\hline E. blastocyst & $\begin{array}{l}\text { GnRH } \\
\text { PMSG+hCG }\end{array}$ & $\begin{array}{l}17 \\
10\end{array}$ & $\begin{array}{c}16(94.12)^{\mathrm{a}} \\
8(80.00)^{\mathrm{a}}\end{array}$ & $\begin{array}{l}13(81.25)^{\mathrm{a}} \\
5(62.50)^{\mathrm{b}}\end{array}$ & $\begin{array}{l}12(92.31)^{\mathrm{a}} \\
4(80.00)^{\mathrm{a}}\end{array}$ \\
\hline Total & & 413 & $349(84.50)$ & $250(71.63)$ & $152(60.80)$ \\
\hline $\begin{array}{l}{ }^{1} \text { Percentage ba } \\
{ }^{2} \text { Percentage ba } \\
{ }^{3} \text { Percentage ba } \\
\text { C. Morulae }=\text { C } \\
\text { a,b Values with } \\
\text { significantly (P }\end{array}$ & $\begin{array}{l}\text { on the numb } \\
\text { ected morul } \\
\text { 5). }\end{array}$ & $\begin{array}{l}\text { number } \\
\text { embryo } \\
\text { morpho } \\
\text { d E. blas }\end{array}$ & $\begin{array}{l}\text { nbryos recov } \\
\text { fified. } \\
\text { ally normal e } \\
\text { st= Early bla } \\
\text { e column w }\end{array}$ & $\begin{array}{l}\text { os post-thawing. } \\
\text { t. }\end{array}$ & \\
\hline
\end{tabular}




\section{CONCLUSION}

It could be concluded that when treating rabbit donors with GnRH prior to embryo cryopreservation programs is remarkably effective towards the production and recovery of morphologically good quality embryos and that although embryos at 2-cell to early blastocyst stages could be vitrified, yet, embryos at morula to blastocyst stages exhibited higher resistance to the negative effects of vitrification on viability when cultured in vitro.

\section{REFERENCES}

Al-Hasani, S., Kirsch, J., Diedrich, K., Blanke, S. van der Ven, H. and Krebs, D. (1989). Successful embryo transfer of cryopreserved and in vitro fertilized rabbit oocytes. Hum Reprod, 4:77-79.

Bakker, J. and Baum, M.J. (2000). Neuroendocrine regulation of GnRH release in induced ovulators, Front Neuroendocrinol, 21:220-262.

Ben Jeraba, M.K., Carrière, P.D. and Price, C.A. (1994). Decreased pulsatile LH secretion in heifers superovulated with eCG or FSH, Theriogenology 42: 685-694.

Carney, E.W. and Foote, R.H. (1990). Effects of superovulation, embryo recovery, culture system and embryo transfer on development of rabbit embryos in vivo and in vitro, Journal of Reproduction and Fertility, 89: 543-551.

Chrenek, P., Makarerich, A., Vasicek, D., Laurincik, J., Bulla, T. and Gajarska, T. (1998). Effects of superovulation, culture and microinjection on development of rabbit embryos in vitro, Theriogenology, 50: 659-666.

Gajda, B. and Smorag, Z. (1993). Factors affecting the survival of one- and two-cell rabbit embryos cryopreserved by vitrification, Theriogenology 39, pp. 499-506.

Garcia, M.L., Viudes DE Castro, M.P., Vicente, J.S. and Baselga, M. (2000). Efficiency of cryopreservation programmes in the re-activation of a maternal rabbit line. Proc. $7^{\text {th }}$ World Rabbit Congress. 371-378.

García-Ximénez, F. and Vicente, J.S. (1992). Effect of ovarian cystic or haemorrhagic follicles on embryo recovery and survival after transfer in hCG ovulated rabbits. Nutr. Reprod. Dev., 32: 143-149.

García-Ximénez, F. and Vicente, J.S. (1990). Effect of PMSG treatment to mating interval on the superovuatory response of primiparous rabbits, Journal of Applied Rabbit Research, 13: 71-73.

Gosselin, N., Price, C.A., Roy, R. and Carrière, P.D. (2000). Decreased LH pulsatility during initiation og gonadotropin superovulation treatment in the cow: evidence for negative feedback other than estradiol and progesterone, Theriogenology 54: 507-521. 
Hochi, S., Hirabayashi, M., Hirao, M., Kato, M., Kobayashi, T., Kimura, K., Hirasawa, K., Leibo, S.P. and Ueda, M. (2001). Effects of cryopreservation of pronuclear-stage rabbit zygotes on the morphological survival, blastocyst formation, and full-term development after DNA microinjection. Molecular Reproduction and Development, 60:227-232.

Kasai, M., Hamaguchi, Y., Zhu, S.E., Miyake, T., Sakurai, T., Machida, T. (1992). High survival of rabbit morulae after vitrification in an ethylene glycol-based solution by a simple method. Biology of Reproduction, 46: 1042-1046.

Kasai, M., Zhu, S.E., Pedro, P.B., Nakamura, K., Sakurai, T. and Edashige, K. (1996). Fracture damage of embryos and its prevention during vitrification and warming, Cryobiology 33, 459-464.

Kauffman, R.D., Schmidt, P.M., Rall, W.F. and Hoeg, J.M. (1998). Superovulation of rabbits with FSH alters in vivo development of vitrified morulae, Theriogenology (50): 1081-1092.

Kennelly, J.J. and Foote, R.H. (1965). Superovulatory response of pre- and postpubertal rabbits to commercially available gonadotropins, Journal of Reproduction and Fertility, 9: 177-188.

Kobayashi, K., Nagashima, H., Yamakawa, H., Kato, Y., Ogawa, S. (1990). The survival of whole and bisected rabbit morulae after cryopreservation by the vitrification method. Theriogenology, 33: 777-788.

Kojima, T, Soma, T and Oguri, N. (1987). Effect of rapid addition and dilution of dimethyl sulfoxide and $37^{\circ} \mathrm{C}$ equilibration on viability of rabbit morulae thawed rapidly. Cryobiology, 24: 247-55.

Leoni, G., Berlinguer, F., Roseti, I., Bogliolo, L., Ledda, S. and Naitana, S. (2003). Resumption of metabolic activity of vitrified/warmed ovine embryos, Mol Reprod Dev 64, 207-213.

Leoni, G., Bogliolo, L., Pintus, P., Ledda, S. and Naitana, S. (2001). Sheep embryos derived from $\mathrm{FSH} / \mathrm{eCG}$ treatment have a lower in vitro viability after vitrification than those derived from FSH treatment, Reprod Nutr Dev 41, 239-246.

Lopez-Bejar, M. and Lopez-Gatius, F. (2002). Nonequilibrium cryopreservation of rabbit embryos using a modified (sealed) open pulled straw procedure. Theriogenology. 58:1541-1552.

Lopez-Bejar, M., Lopez-Gatius, F., Camon, J., Rutllant, J., Labernia, J. (1994). Development in vitro of rabbit embryos after freezing by two-step or ultra-rapid cooling methods. J Vet Med A., 41(10):780-790.

Maertens, O.W., Petres, S. and Couve E. (1995). A simple serum-free freezing medium for serum-free cultured cells. Biologicals, 23:185-9.

Mazur, P., Rall, W.F. and Leibo, S.P. (1984). Kinetics of water loss and the like lihood of intracellular freezing in mouse ova. Cell Biophys, 6: 197-213. 
Mehaisen, G.M.K., Vicente, J.S., Lavara, R. and Viudes DE Castro, M.P. (2005). Effect of eCG dose and ovulation induction treatments on embryo recovery and in vitro development post-vitrification in two selected lines of rabbit does. Animal Reproduction Science, 90 (11): 175-184.

Mehaisen, G.M.K., Viudes DE Castro, M.P., Vicente, J.S. and Lavara, R. (2006). In vitro and in vivo viability of vitrified and non-vitrified embryos derived from eCG and FSH treatment in rabbit does. Theriogenology, 65 (7): 1279-1291.

Meshreky, Samia Z. and Salama, O. A. (2005). In vivo and in vitro rabbit embryo production and development: a comparative study. The $4^{\text {th }}$ Inter. Con. on Rabbit Prod. in Hot Clim., Sharm El-Sheikh, Egypt,211-223

Mocé, M.L., Santacreu, M.A., Climent, A., Peiro, R., Blasco, A. (2004). In vivo development of vitrified rabbit embryos: effects on prenatal survival. In: Proceedings of the $8^{\text {th }}$ World Rabbit Congress of Preliminary Results, Mexico; 309-314.

Nagashima, H., Kashiwazaki, N., Ashman, R.J., Grupen, C.G. and Nottle, M. (1995). Cryopreservation of porcine embryos. Nature, 374:416.

Ogawa, S. and Tomoda, S. (1976). Survival of 16-celled and morula stage rabbit embryos frozen to -196 degrees C. Jikken Dobutsu., 25(4): 273-282.

Papis, K., Sypecka, J., Korwin-Kossakowski, M., Wenta-Muchalska, E. and Bilska, B. (2005). Banking of embryos of mutated, paralytic tremor rabbit by means of vitrification. Laboratory Animals, 39(3): 284-289.

Parvex, R. (1982). Etude comparée de développement in vitro, in vivo et après congélation d'embryons de lapin produits avec ou sans superovulation, Thése de troisiéme cycle, Université Pierre et Marie Curie, Paris. Cited by Mehaisen et al. (2006).

Pollard, J.W. and Leibo, S.P. (1994). Chilling sensitivity of mammalian embryos. Theriogenology, 41: 101-106.

Ramirez, V.D. and Beyer, C. (1998). The ovarian cycle of the rabbit: its neuroendocrine control. In: E Knobil and J.D. Neil, Editors, The physiology of reproduction vol. 2, Raven Press, 1873-1892.

Rebollar, P.G., Ubilla, E., Lorenzo, P.L., Sánchez-Dávil, M., Sánchez, J., Tucker, L., Alvaiño, J.M.R. (2000). Ovulation and embryo implantation rate in synchronised artificial inseminated multiparous lactating does. In: Proceedings of the 7th World Rabbit Congress, vol. A, Valencia, Spain; 239-244.

Renard, J.P., Garnier, V. and Parvex, R. (1982). Production et congélation de ĺembryon de lapin. 3es Journées de la Recherche Cunicole en France. Comunication no. 18. Cited by Mehaisen et al. (2006).

Salvetti, P., Theau-Clément, M., Beckers, J.F., Hurtaud, J., Guérin, P., Neto, V., Falières, J. and Joly, T. (2007). Effect of the luteinizing hormone on embryo production in superovulated rabbit does. Theriogenology, 67 (4): 1185-1193. 
Schmidt, P.M., Hollifield, V.M., Lin, X. and Wildt, D.E. (1992). Induced ovulation and adequate embryo recoveries in New Zealand White rabbits treated with a low PMSG/HCG dose or single, daily injections of FSH-P, Theriogenology 37: 293 [abstract].

Schneider, U. and Mazur, P. (1984). Osmotic consequences of cryoprotectant permeability and its relation to the survival of frozen-thawed embryos. Theriogenology, 21: 68-79.

Smorag, Z. and Gajda, B. (1998). In vitro and in vivo survival of rabbit embryos vitrified in EFS medium and increased PBS salt concentration. Cryo Lett;19: 99104.

Smorag, Z, Gajda B,Wieczorek B, Jura J. (1989). Stagedependent viability of vitrified rabbit embryos. Theriogenology, 31: 1227-1231.

Takagi, M., Kim, I.H., Izadyar, F., Hyttel, P., Bevers, M.M. and Dielman, S.J. (2001). Impaired final follicles maturation in heifers after superovulation with recombinant human FSH. Reproduction, 121, 941-951.

Vajta, G. (2000). Vitrification of oocytes and embryos of domestic animals, Animal Reproduction Science, 61: 357-364.

Vincente, JS and Garcia-Ximenez F. (1994). Osmotic and cryoprotective effects of mixture of DMSO and ethylene glycol on rabbit morulae. Theriogenology, 42: 1205-1215.

Vincente, C., Garnier, V., Heyman, Y. and Renard J.P. (1989). Solvent effects on cytoskeltal organization and in vivo survival after freezing of rabbit oocytes. $J$. Reprod Fertil, 87: 809-820.

Vicente, J.S., Viudes DE Castro, M.P. and Garcia, M.L. (1999). In vivo survival rate of rabbit morulae after vitrification in a medium without serum protein. Reprod. Nutr. Dev. 39: 657-662.

Vicente, J.S., Viudes DE Castro, M.P., Garcia, M.L. and Baselga, M. (2003). Effect of rabbit line on a program of cryopreserved embryos by vitrification, Reprod Nutr Dev 43: 137-143.

Viudes DE Castro, M.P., García-Ximénez, F. and Vicente, J.S. (1995). Embryo recovery from eliminating does of three selected rabbit strains for an embryo bank, Investigación Agraria: Producción y Sanidad Anim, 10: 145-152.

Yaakub, H., Duffy, P., Callaghan, D.O. and Boland, M.P. (1998). Effect of timing of oestradiol benzoate injection relative to gonadotrphin treatment on superovulatory response and on yield and quality of beef heifers, Animal Reproduction Science, 52: 191-204. 


\section{تطور أجنة الأرانب المجمدة خارج الجسم: تأثثير معاملة الإناث هرمونياو مراحل تطور الجنين}

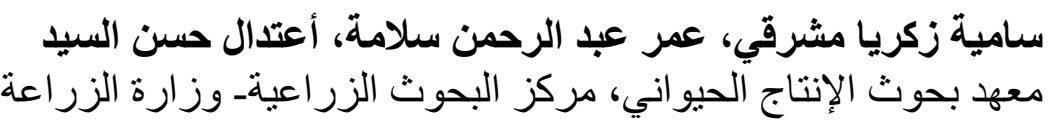

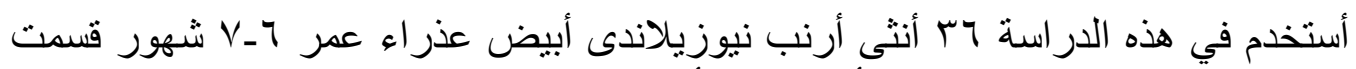

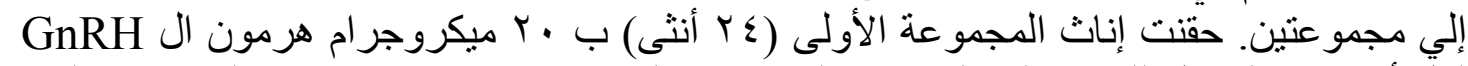

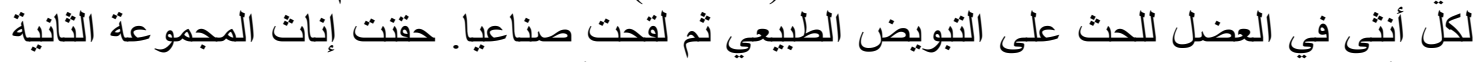

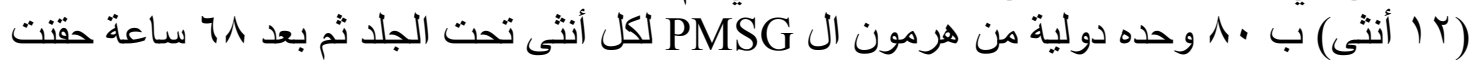

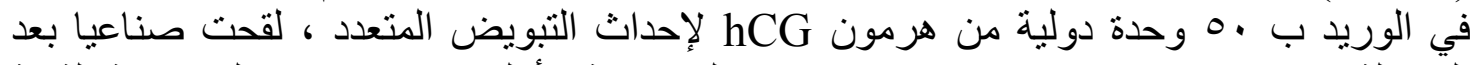

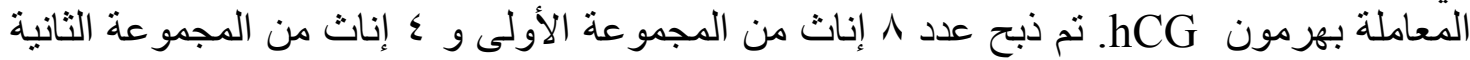

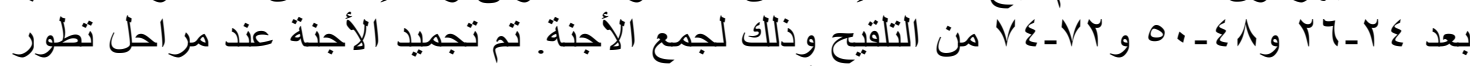

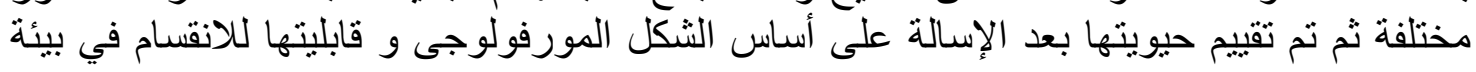
الاستزر اع.

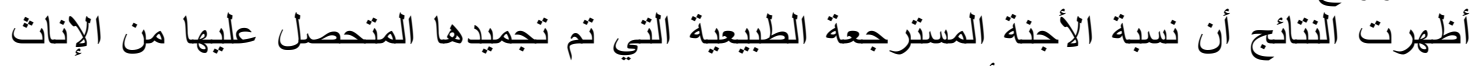

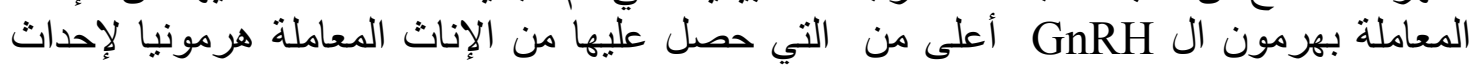

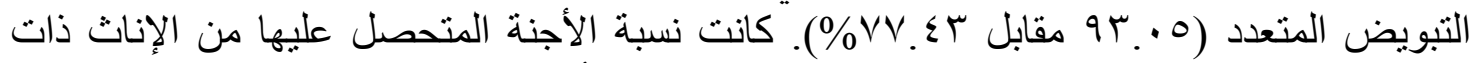

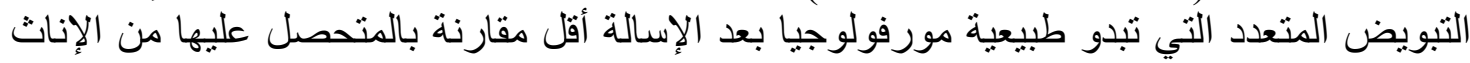

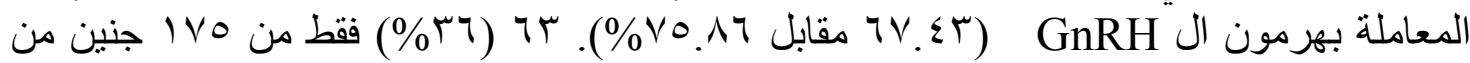

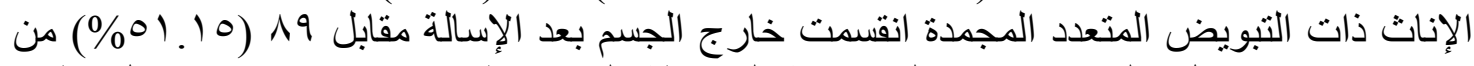

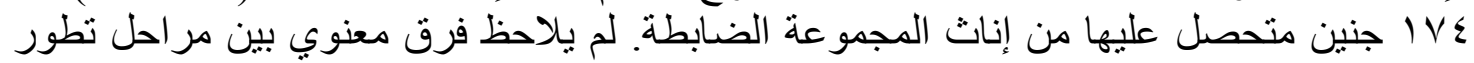

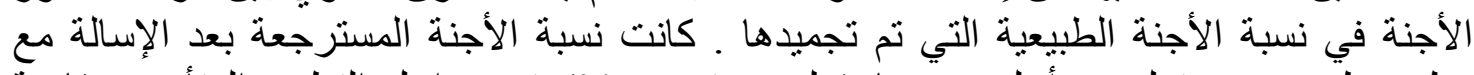

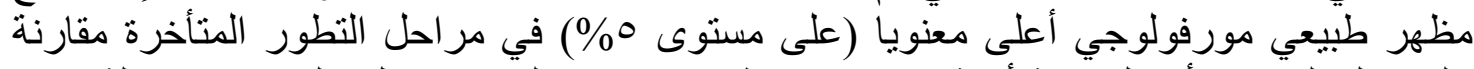

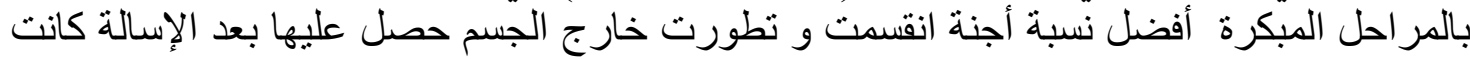

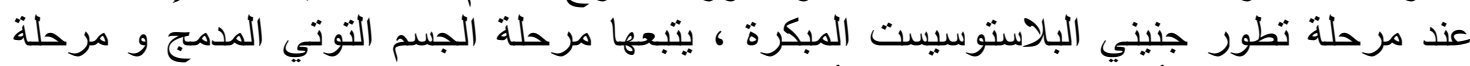

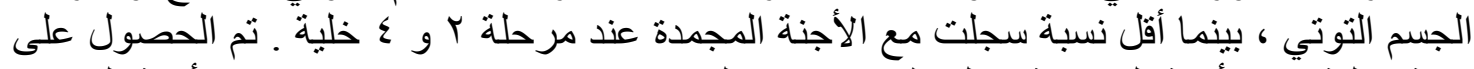

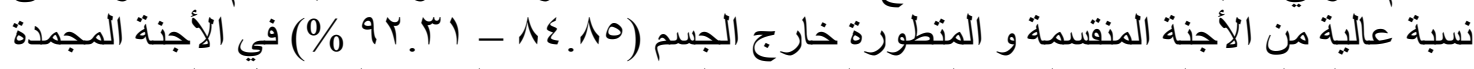

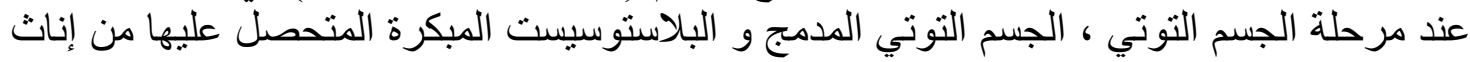

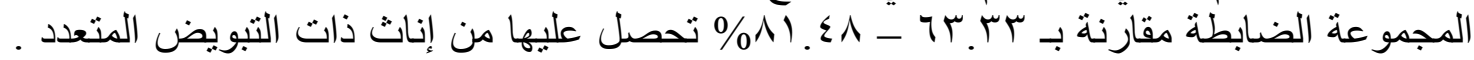

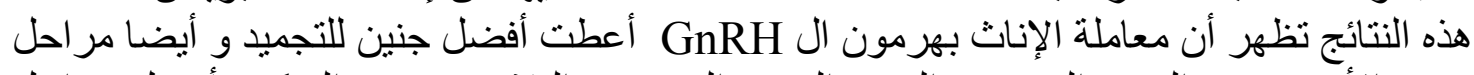

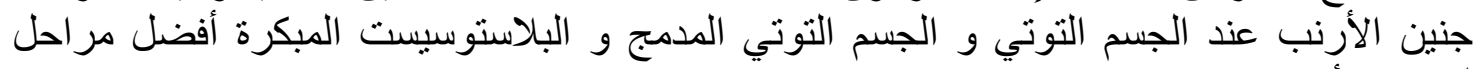
لتجمبد الأجنة. 